\title{
Supplement 2.
}

Best fit distributions for all determinations.

The table reports D-statistics and p-values of the KS goodness of fit test for each of the 84 data sets. The KS test for goodness of fit performs a test of the distribution of an observed random variable against a given distribution under the null hypothesis that the two distributions are identical. The table also reports the MLEs for shape, location and scale parameters obtained from the maximum likelihood estimation needed to perform the KS tests. We fitted the data to the following distributions: beta, exponential, exponential-Weibull, exponential-power law, Gilbrat, logistic, lognormal, normal, Pareto, power law, Weibull minimum, and Weibull maximum.

\section{M: MALE \\ F:FEMALE}

\begin{tabular}{|c|c|c|c|c|c|c|c|c|c|}
\hline \multicolumn{10}{|c|}{ Goodness of fit test results } \\
\hline & & & $\begin{array}{l}\text { Best fit } \\
\text { distribution }\end{array}$ & \multicolumn{2}{|c|}{ KS test } & \multicolumn{4}{|c|}{ Best fits MLEs (shape, c, location, and scale) } \\
\hline & & $\begin{array}{l}\text { Gen } \\
\text { der }\end{array}$ & & D-statistic & p-value & $\mathbf{S}$ & $\mathbf{C}$ & LOC & SCALE \\
\hline \multicolumn{10}{|l|}{ Arginine } \\
\hline \multirow{4}{*}{ Control } & \multirow{2}{*}{$\mathrm{RBC}$} & $\mathrm{M}$ & lognormal & 0.16428 & 0.20659 & 0.376438 & & 1.308643 & 5.47568 \\
\hline & & $\mathrm{F}$ & lognormal & 0.1665159 & 0.194354 & 1.29766 & & 3.436246 & 0.67795 \\
\hline & \multirow{2}{*}{ Serum } & M & logistic & 0.1058 & 0.76317 & & & 0.18254 & 0.037755 \\
\hline & & F & Power law & 0.149034 & 0.306546 & 1.45524 & & 0.0614427 & 0.207557 \\
\hline \multirow{4}{*}{ Diabetics } & \multirow{2}{*}{ RBC } & $\mathrm{M}$ & logistic & 0.123167 & 0.548778 & & & 5.46838 & 0.747606 \\
\hline & & $\mathrm{F}$ & logistic & 0.185849 & 0.110702 & & & 7.314805 & 1.144642 \\
\hline & \multirow[b]{2}{*}{ Serum } & M & lognormal & 0.131201 & 0.4633701 & 0.501445 & & 0.01789 & 0.114442 \\
\hline & & $\mathrm{F}$ & $\begin{array}{l}\text { Exponential } \\
\text { weibull }\end{array}$ & 0.1779749 & 0.1402727 & 264.953 & 0.348029 & 0.056437 & 0.00075 \\
\hline
\end{tabular}




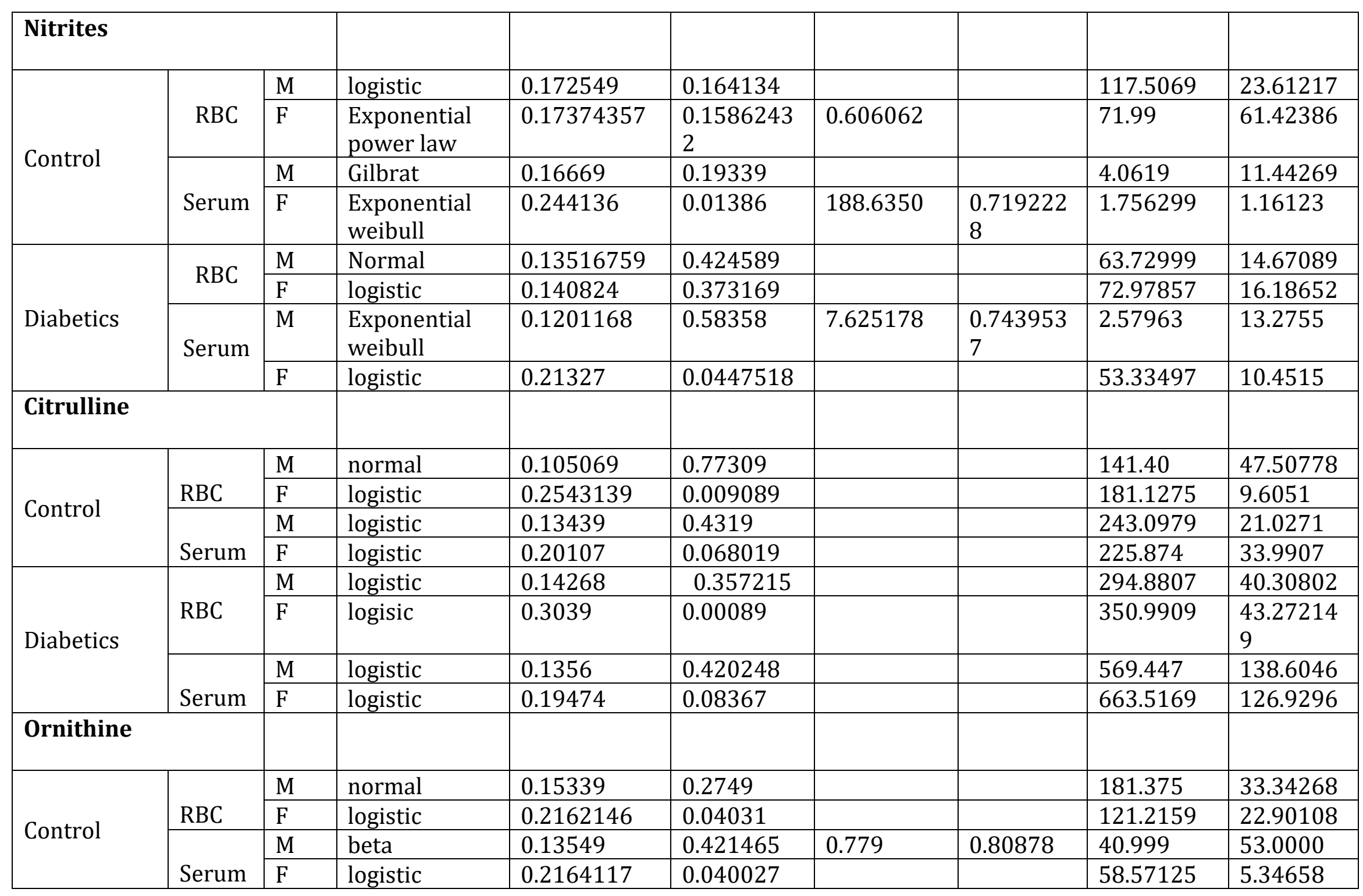




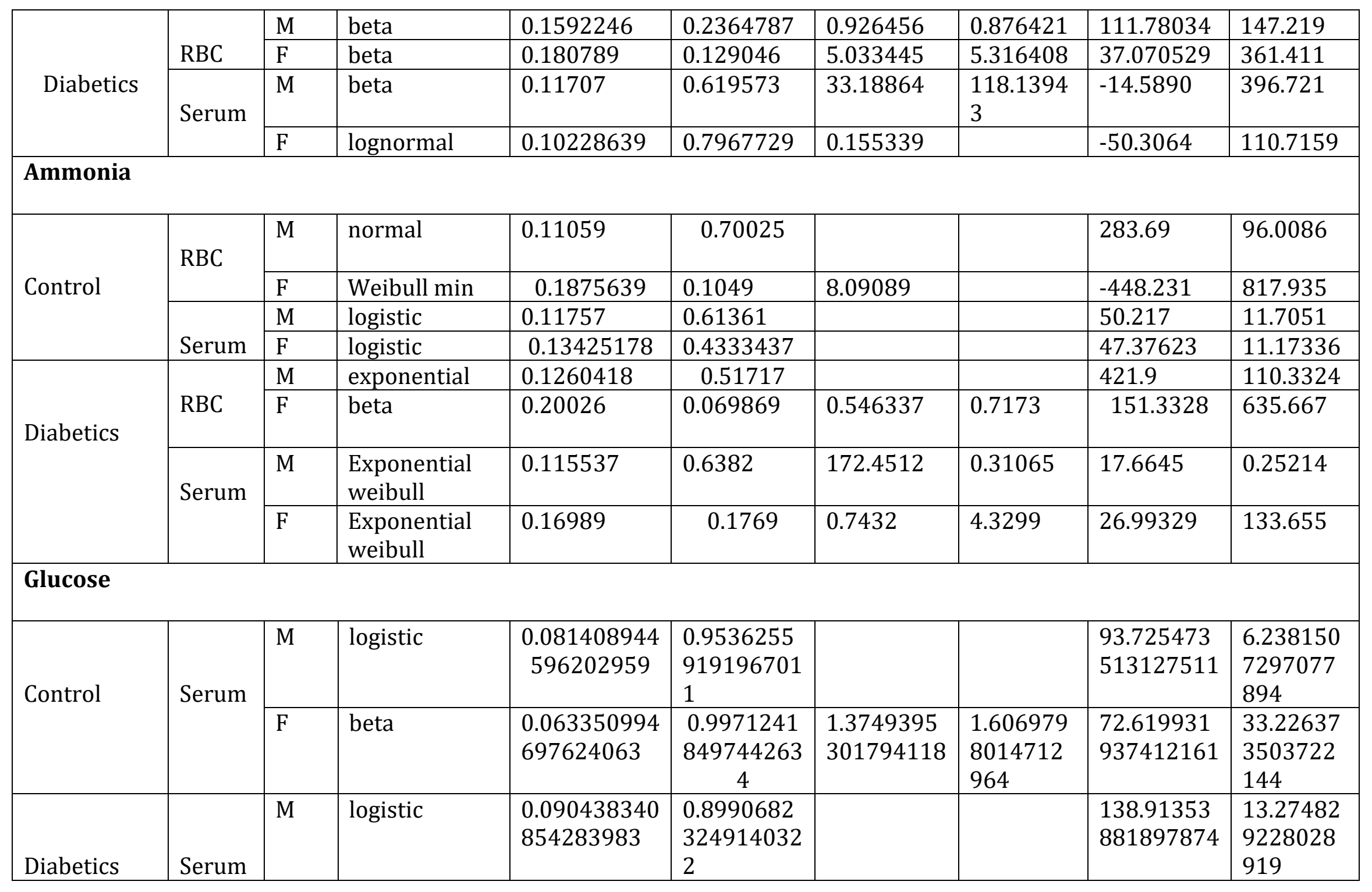




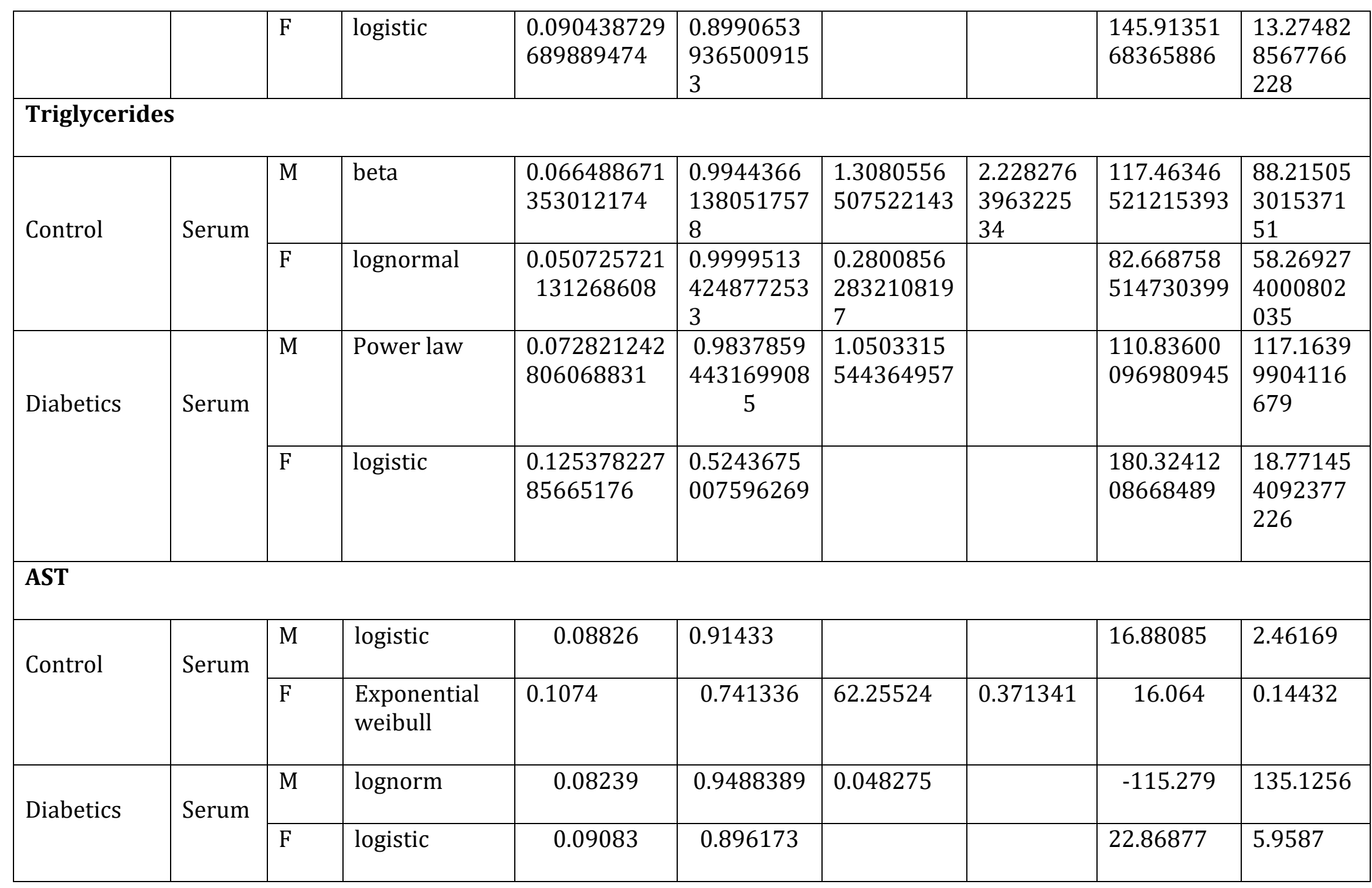




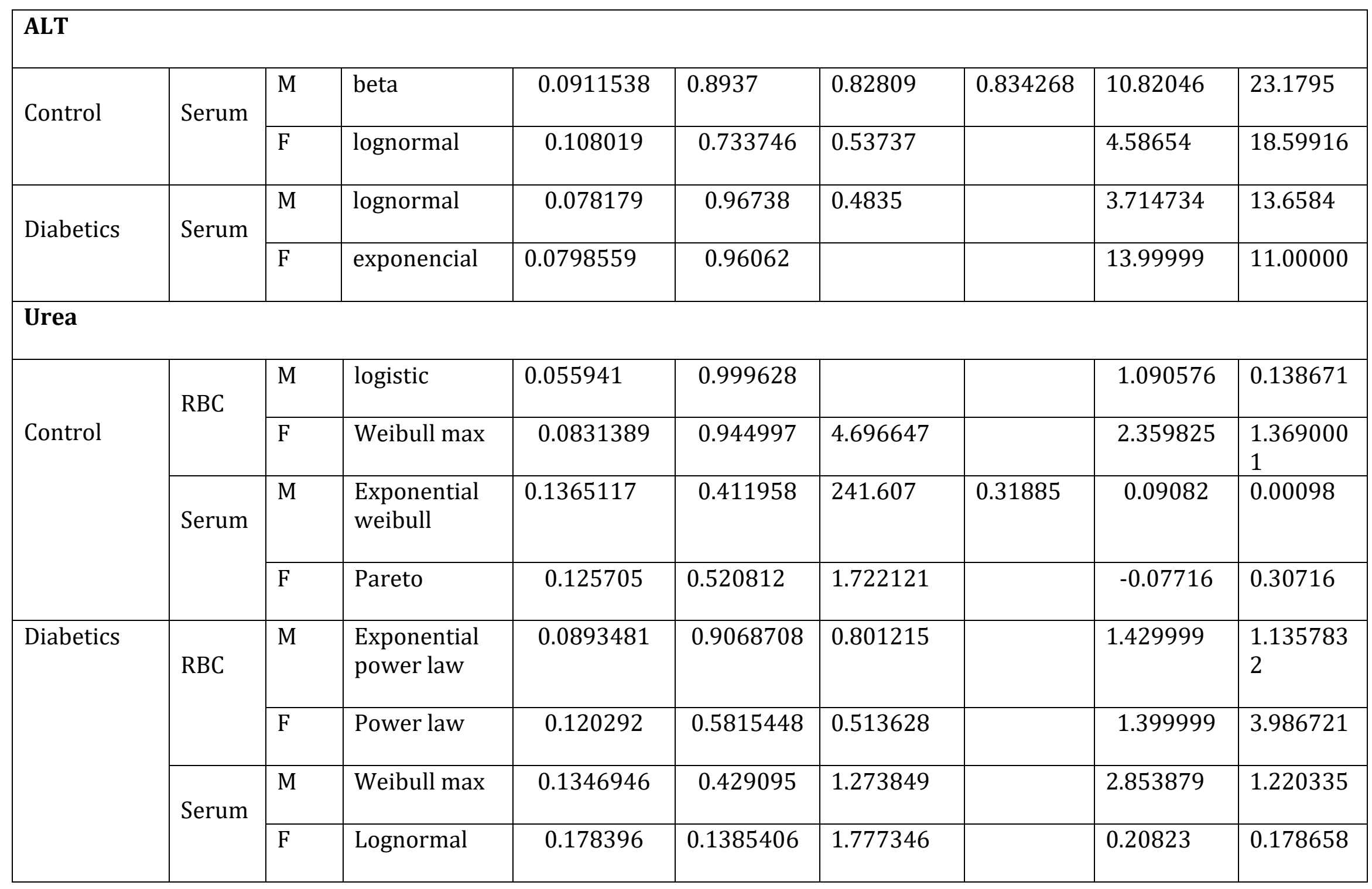




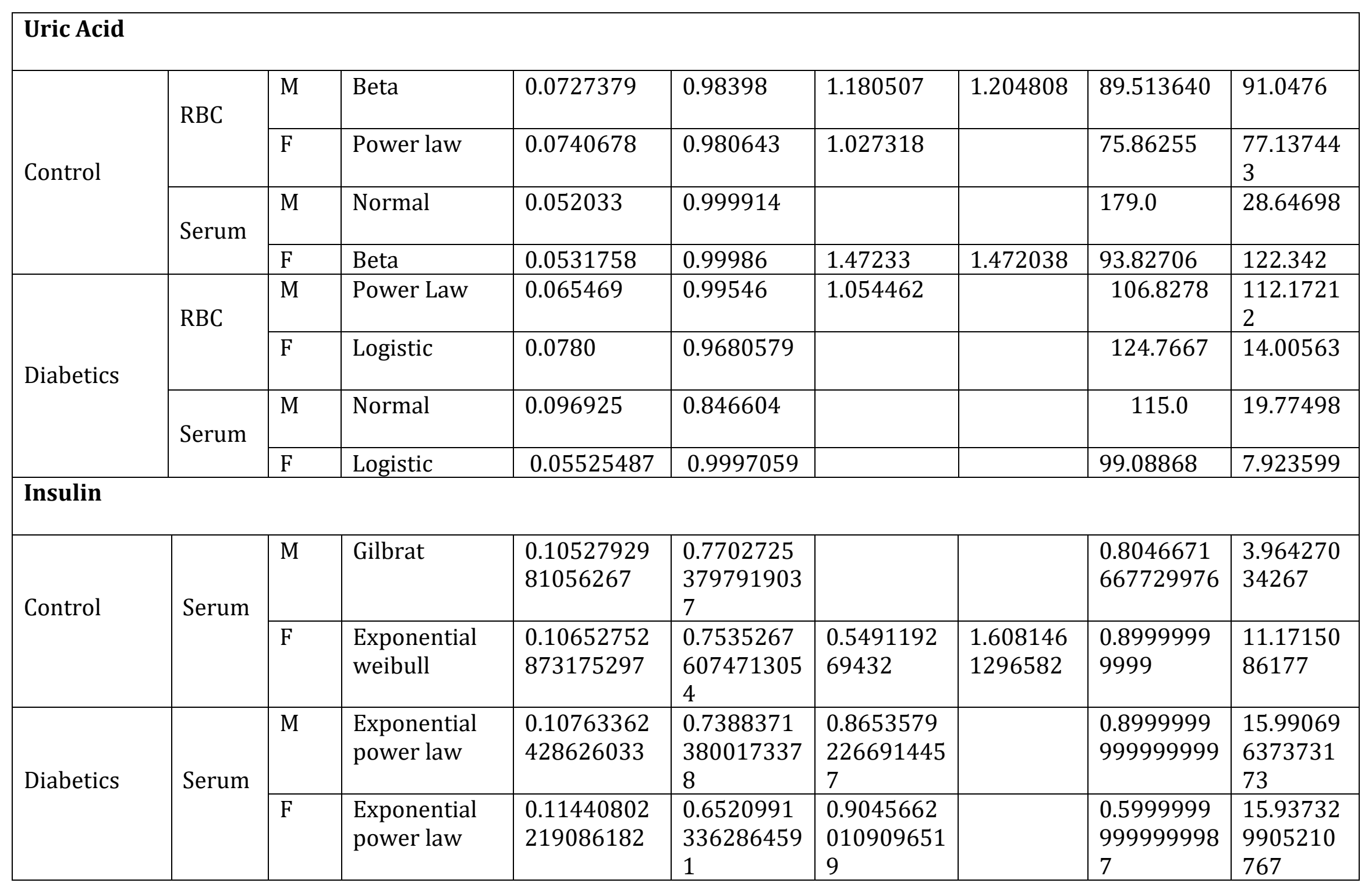




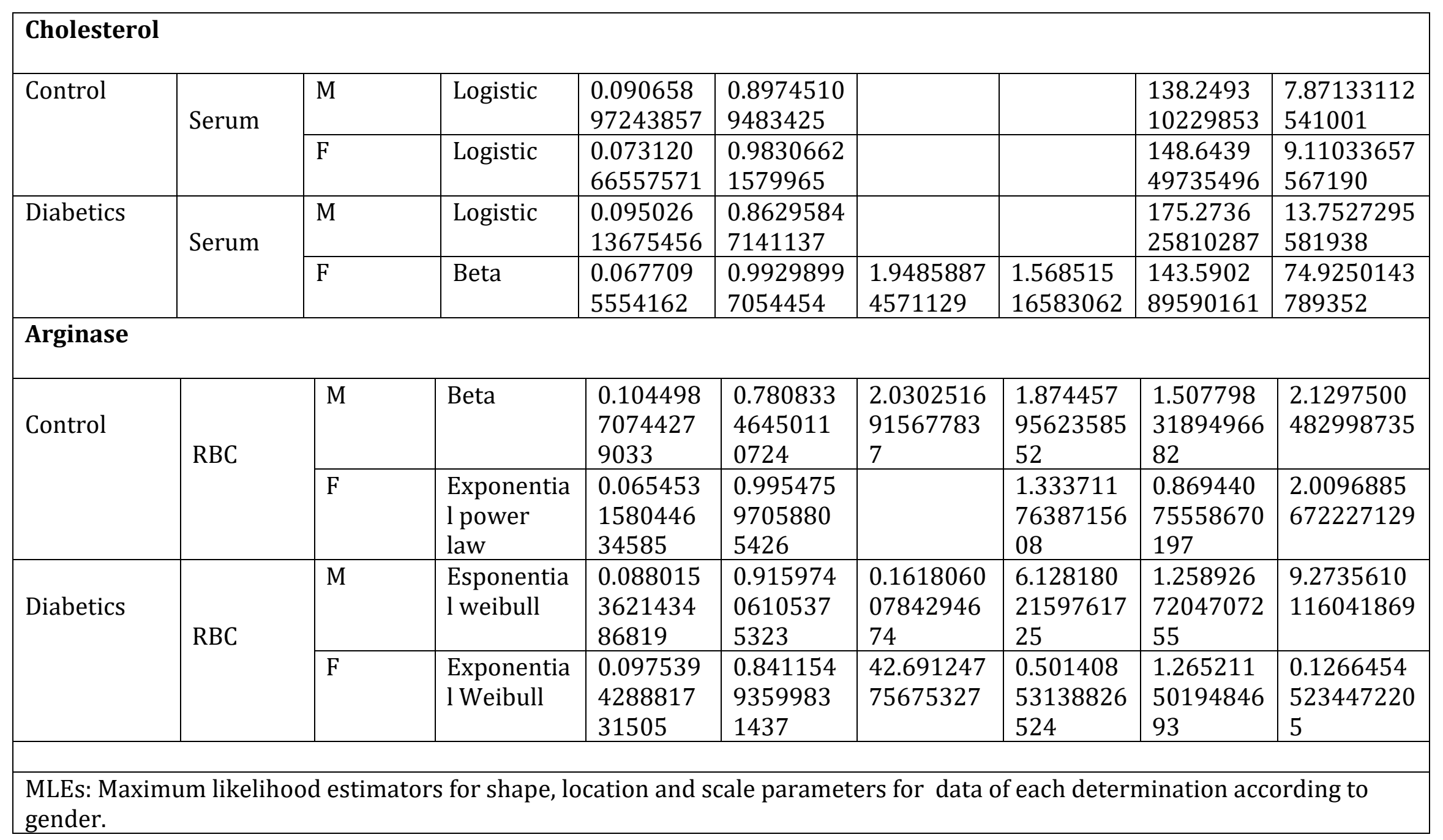

